Original Research Paper

\title{
Effect of Bacterial Inoculants on Agronomic Performance of Three Genotypes of Potato (Solanum tuberosum L.) in Coastal Areas of Peru
}

\author{
${ }^{1}$ Sergio Eduardo Contreras Liza, ${ }^{2}$ Juan Carlos Custodio Laura, \\ ${ }^{3}$ Doris Elizabeth Zúñiga Dávila and ${ }^{3}$ Sady García Bendezú \\ ${ }^{1,3}$ Universidad Nacional Agraria La Molina, Lima-Perú. Peru \\ ${ }^{2}$ Agronomist, Universidad Nacional José Faustino Sánchez Carrión, Huacho-Peru
}

Article history

Received: 24-06-2017

Revised: 5-09-2017

Accepted: 31-10-2017

Corresponding Author:

Sergio Eduardo Contreras-Liza

Universidad Nacional Agraria

La Molina. Lima-Perú, Peru

Tel: +511971759585

Email: scontreras@unjfsc.edu.pe

\begin{abstract}
To study the effect of interaction of plant genotypes and populations of microorganisms in the rhizosphere may be an important factor to assess the effectiveness of PGPRs on crop production. The objective of this research was to determine the effect of inoculation of four bacterial strains on the agronomic performance of three commercial cultivars of potato in the province of Cañete, Peru. A randomized complete blocks design with three replications on a split plot arrangement was used, in which potato genotypes (three commercial varieties) were assigned to complete plots and inoculation treatments (bacterial strains and control) were allocated to sub-plots, then evaluating the effect for growth promotion related to bacterial strains: Bacillus amyloliquefaciens, B. simplex, Azotobacter sp. and Pantoea sp. on potato agronomic characteristics. As result of inoculation with bacterial strains in potato cultivars Canchán, Perricholi and Unica, significant differences were showed $(p<0.05)$ for vegetative vigor, percentage of inflorescences per plant, foliage weight per plant and weight of the total biomass per hectare with use of inoculation of some of these strains, having a stimulatory effect on development in these commercial varieties, highlighting strain AZO16 M2 (Azotobacter sp.) to promote increased weight of foliage and total biomass and flowering in cv. Perricholi and strain Bac15MB (Bacillus amyloliquefaciens) to regulate the degree of senescence of foliage, specifically in cv. Canchan. Concluding that inoculation with bacterial strains in potato cultivars Canchan, Perricholi and Unica influenced some important crop agronomic characters, although its specific effect was dependent on each potato variety.
\end{abstract}

Keywords: Potato Cultivars, PGPR Inoculation, Plant-Microbe Interactions

\section{Introduction}

In the decade of $1960-2000$, potato production in Peru increased from 1.3 to 3 million tons per year according to Maldonado et al. (2008). This volume of production has made the country's largest potato producer in Latin America. On the other hand, it is known that the potato crop is very sensitive to a number of biotic and abiotic environmental stresses; potato diseases can greatly reduce productivity and tuber quality (FAO, 2008). These problems, coupled with the fact that potato is propagated by vegetative means, make crop health as a considerable problem for the production of quality planting material. The virtues of potatoes, particularly its high nutritional value and their ability to increase farmers' income, have not been the attention they deserve from governments (FAO, 2008), so it is necessary to invest in new technologies with potential to reduce the risk of the crop.

Many bacterial strains with important biological activity, belonging to the genera Azoarcus, Azospirillum, Azotobacter, Arthrobacter, Bacillus, Clostridium, Enterobacter, Gluconacetobacter, Pseudomonas and Serratia, have been reported (Maheshwari, 2011); including importantly the species Pseudomonas sp. and Bacillus sp. as the most 
extensively studied. Ecological factors such as temperature and nutrient soil conditions affect the behavior of rhizobacteria; bacterial inoculation has a better stimulatory effect of plant growth under conditions of nutrient-deficient soils or rich fertile soils (Egamberdieva, 2012).

Under controlled conditions Bacillus sp. produce clues to the underlying mechanisms of better growth of potato plants as early tuberization, rapid development of leaf area and probably higher rate of photosynthesis (Oswald et al., 2010). Calvo et al. (2008) observed an effect of potato variety on populations of microorganisms in the rhizosphere, confirming the influence of plant exudates on the rhizosphere populations.

Some beneficial microorganisms such as promoting rhizobacteria plant growth and mycorrhizal fungi, may have mediated the effect of plant phytophagous insects; the plant growth promoting rhizobacteria Pseudomonas fluorescens can induce systemic resistance in Arabidopsis thaliana against several microbial pathogens and chewing insects (Pineda et al., 2012).

High prevalence of antagonistic microorganisms was found in bacterial native strains for soil pathogen Rhizoctonia solani; even more, these strains inhibited the growth of Fusarium solani, showed a certain level of auxin indole-3-acetic acid and participate in the solubilization of tri-calcium phosphate. Phylogenetic analysis revealed that most strains belonging to species B. amyloliquefaciens, while strains Bac17M11, Bac20M2 and Bac20M1, as a new group of putative Bacillus sp. (Calvo and Zúñiga, 2010).

The ability of plant growth promotion in strains of Azotobacter sp. and actinomycetes isolated from potato fields in the Andean highlands of Peru, was evaluated by Rico (2009). He found that $42.3 \%$ of strains inhibited the growth of Fusarium solani and $17 \%$ of Rhizoctonia solani; also that $56.5 \%$ of Azotobacter strains produced indole acetic acid (auxin) and $46.7 \%$ produced phosphate solubilization halos. Most Azotobacter isolates were recognized as A. chroococcum and A. vinelandii. At greenhouse conditions, Azotobacter strains showed promotion of plant growth in root crops.

The aim of this research was to determine the interactive effect of bacterial strains and commercial cultivars of potato on the agronomic performance in field conditions of the province of Cañete (Peru) and to propose alternatives to the use of external chemical inputs in potato cultivation, favoring the development of plant defenses through the application of biological inducers to increase and improve natural immunity and agronomic performance in farmer fields.

\section{Materials and Methods}

\section{Materials}

Seed-potato tubers from in vitro plantlets of cultivars "Unica" CIP number 392797.22 (Gutiérrez-Rosales et al.,
2007), "Perricholi" CIP number 374080.5 and "Canchan" CIP number 380389.1 (CIP, 2013) were provided by International Potato Center (CIP Genebank, Lima) and selected considering their vigor and emergence of sprouts, verifying that were free of pests or diseases.

The biological material (bacterial strains) was provided by Laboratorio de Ecología Microbiana y Biotecnología Marino Tabusso at Universidad Nacional Agraria La Molina (Lima). For the purpose of the experiment, inoculation was carried out with the following bacterial strains isolated from the rhizosphere of potato (Calvo and Zúñiga, 2010):

- Bacillus amyloliquefaciens strain Bac15MB

- Bacillus simplex strain B13

- Azotobacter sp. strain AZO16M2

- $\quad$ Pantoea sp. strain DZ22

\section{Experimental Site}

Field research was conducted during the spring season at district Quilmaná, located at province of Cañete, between the geographical coordinates $12^{\circ} 57$ '34"S and $76^{\circ} 23^{\prime} 17^{\prime}$ ' $\mathrm{W}$, on average height 151 masl. The weather during the trial was characterized by average temperatures between 16 and $24^{\circ} \mathrm{C}$, relative humidity of $82-84 \%$ and $2 \mathrm{~mm}$. for monthly rainfall. The soil had the following characteristics: organic matter $0.76 \%, \mathrm{CaCO}_{3}$ $0.93 \%$, electrical conductivity $3.40 \mathrm{dS} . \mathrm{m}^{-1}, \mathrm{pH} 7.84$, $16.68 \mathrm{ppm}$ available phosphorus, $154 \mathrm{ppm}$ available potassium, cation exchange capacity $7.83 \mathrm{meq}$ per $100 \mathrm{~g}$.

\section{Preparation and Application of Treatments}

In a conditioned area were measured the amounts of each bacterial strain used as separated treatments for each potato cultivar. A dose of $30 \mathrm{ml}$ pure bacterial inoculum (density of ca. $10^{8}$ cfu. $\mathrm{mL}^{-1}$ ) was used for each treatment and additionally four liters of deionized water to make the immersion of the whole planting material and being impregnated bacterial inoculants in seed tubers. Then, immediately proceeded to the field planting at density of 30000 plants per hectare. The control plots were applied at a dose of $0.4 \mathrm{mM}$ acetylsalicylic acid (pharmacological use) in immersion to the tubers; later 15 days after emergence of the plants, the same dose was applied spraying the foliage. In all cases, seed tubers inoculation lasted $5 \mathrm{~min}$, after which they were sown in field plots. For this, a sample of approximately 200 potato tubers were subdivided into 5 batches of 40 tubers for inoculation treatment of each bacterial strain and a control in each repetition. Inoculation treatments with bacterial strains were again applied to plant foliage at 45 days after planting, at a dose of $30 \mathrm{ml}$. pure inoculum (density of ca. $10^{8}$ cfu. $\mathrm{mL}^{-1}$ ) with additional $10 \mathrm{~L}$ current water to each of the four bacterial strains; control treatment (with no bacterial inoculants) were watered on plant foliage. 
A single dose of vermicompost enriched with phosphate rock was applied to the soil at potato planting, equivalent to $7.40 \mathrm{t}$. $\mathrm{ha}^{-1}$. In vermicompost, an average content of $\begin{array}{llllll}1 \% & \mathrm{~N}, 2.5 \% & \text { and } & 0.5 \% & \mathrm{~K}_{2} \mathrm{O} & \mathrm{P}_{2} 0_{5}\end{array}$ (Pineda, 1999), equivalent as dose per hectare of $74 \mathrm{~kg}$ nitrogen, $185 \mathrm{~kg}$ $\mathrm{P}_{2} \mathrm{O}_{5}$ and $37 \mathrm{~kg} \mathrm{~K} \mathrm{~K}_{2} \mathrm{O}$. During cropping period, no fungicides were applied and chemical control for pests was applied against leafminer fly (Liryomiza huidobrensis) with Abamectina and Cyromazine.

\section{Experimental Design and Statistical Analysis}

A completely randomized design was used with 3 replications on a hierarchical arrangement of split plots (Steel, Torrie \& Dickie, 1997) in which potato genotypes (3 cultivars) were assigned to whole plots and 5 treatments of inoculation (4 bacterial strains + control), were allocated to sub-plots. Both plots and sub-plots were randomized in blocks. Analysis of variance was performed and Tukey test was used with a significance level $\alpha=5 \%$. For systematization of information, a spreadsheet (Excel) was used and InfoStat Software (Balzarini et al., 2014) for statistical processing of field data.

\section{Traits Evaluated}

The variables for field evaluation were: number of sprouts per plant at 15 days after planting, density of plants per plot emerged at 30 days after sowing, vegetative vigor measured as a phenotypic scale of 1 to 9, plant height 60 days after planting, percentage of plants with visual symptoms of virus infection (data transformed to square root), percentage of damaged plants with leaf miner fly (Liriomyza huidobrensis) at 60 days, percentage of affected plants with Rhizoctonia solani 60 days after sowing (square root transformed data), percentage of flowering 75 days after sowing (square root transformed data). Also was evaluated: degree of senescence of foliage at 100 days measured in phenotypic scale from 1 to 9 , fresh weight of foliage at harvest, number of tubers per plot at harvest, weight of tubers per plot at harvest, general appearance of the crop in phenotypic scale from 1 to 9 , average weight of tubers per plant, tuber yield projected for 30000 plants.ha $^{-1}$, total weight of biomass (tuber + foliage) projected per hectare.

\section{Results}

Table 1 and 2 show the results of the analysis of variance for agronomic and productive traits in commercial potato cultivars Canchan, Perricholi and Unica under effect of inoculation with bacterial strains. This analysis shows that all evaluated characters show variation mainly for potato genotypes as expected. Also, there can be noted significant variation for main effects of inoculation with bacterial strains with respect to foliage weight per plot and total weight of biomass per hectare. Other agronomical traits influenced significantly by bacterial inoculants were vegetative vigor and flowering percentage; in the case of interactions of potato genotypes and bacterial strains, there were significant variations for vigor vegetative at 60 days, percentage of flowering at 75 days, foliage weight per plot and total weight of biomass at harvest.

No significant changes were found for sources of inoculation with the bacterial strains or its interactions with potato genotypes with regard to yield of tubers per hectare. Regarding vegetative vigor (Fig. 1) it was showed a significant interaction between potato genotypes and bacterial strains so there was differential response to inoculation with bacterial strains in genotypes of potato, mainly in cv. Unica. In this potato cultivar was observed that control had the lowest value of vigor in relation to bacterial treatments, except for strain DZ22 (Pantoea sp.), in which there were no statistical differences.

In Figure 2 it can be seen that for cv. Perricholi some bacterial strains (AZO16M2, B13 and Bac 15MB) showed a significantly higher level of inflorescences compared to control and strain DZ22. In particular, bacterial strain AZO16M2 (Azotobacter sp.) in potato cv. Perricholi presented a greater effect in relation to percentage of inflorescences compared to control. Canchan and Unica potato cultivars showed no significant flowering.

Table 1: Analysis of variance for agronomic traits in potato genotypes under effect of four bacterial strains

\begin{tabular}{llllllllll}
\hline Sources & Df & NSprouts15d/pl & PDensity30d & Vigor & HPlant & \%Virus & \%LMiner & \%Rhizoctonia & \%Flower \\
\hline Blocks & 2 & NS & NS & NS & NS & NS & NS & NS & NS \\
Genotypes, G & 2 & NS & $*$ & $*$ & $*$ & $*$ & $*$ & $*$ & $*$ \\
Strains, S & 4 & NS & NS & NS & NS & NS & NS & NS & NS \\
S/G & 8 & NS & NS & $*$ & NS & NS & NS & NS & $*$ \\
Total & 44 & & & & & & & & \\
Means & 2.68 & 156.4 & 6.97 & 51.09 & 1.25 & 29.11 & 1.42 & 2.56 & \\
CV, $\%$ & 13 & 15 & 2.5 & 1.8 & 17 & 12 & 25 & 15 & \\
$\mathrm{R}^{2}$ & 0.13 & 0.74 & 0.81 & 1.00 & 0.71 & 0.69 & 0.63 & 0.98 & \\
\hline
\end{tabular}


Sergio Eduardo Contreras Liza et al. / American Journal of Agricultural and Biological Sciences 2017, 12 (3): 139.147 DOI: 10.3844/ajabssp.2017.139.147

Table 2: Analysis of variance for productive traits in potato genotypes under effect of four bacterial strains

\begin{tabular}{|c|c|c|c|c|c|c|c|c|c|}
\hline Sources & Df & Senescence & WFoliage & NTubers & WTubers & HAspect & WTuberc/pl & Yield.ha & Biomass \\
\hline Blocks & 2 & NS & NS & NS & NS & $\mathrm{NS}$ & NS & NS & NS \\
\hline Genotypes, G & 2 & $*$ & $*$ & $*$ & $*$ & $*$ & $*$ & $*$ & $*$ \\
\hline Strains, $\mathrm{S}$ & 4 & NS & * & NS & NS & NS & NS & NS & $*$ \\
\hline $\mathrm{S} / \mathrm{G}$ & 8 & NS & $*$ & NS & NS & NS & NS & NS & $*$ \\
\hline Total & 44 & & & & & & & & \\
\hline Means & & 2.26 & 1.15 & 258.02 & 16.91 & 4.02 & 0.45 & 4.69 & 52.67 \\
\hline $\mathrm{CV}, \%$ & & 20 & 28 & 14 & 13 & 21 & 13 & 13 & 20 \\
\hline $\mathrm{R}^{2}$ & & 0.90 & 0.94 & 0.71 & 0.87 & 0.55 & 0.87 & 0.87 & 0.95 \\
\hline
\end{tabular}

*Values for Mean Squares in bold* are statistically significant $(\mathrm{p}<0.05)$. NS $=$ Non Statistically Significance; $\mathrm{Df}=\mathrm{Degrees}$ of freedom, $\mathrm{S} / \mathrm{G}=$ Interaction of potato genotypes and bacterial strains, $\mathrm{CV}, \%=$ Coefficient of variability expressed in percentage, $\mathrm{R}^{2}=\mathrm{Coefficient}$ of determination

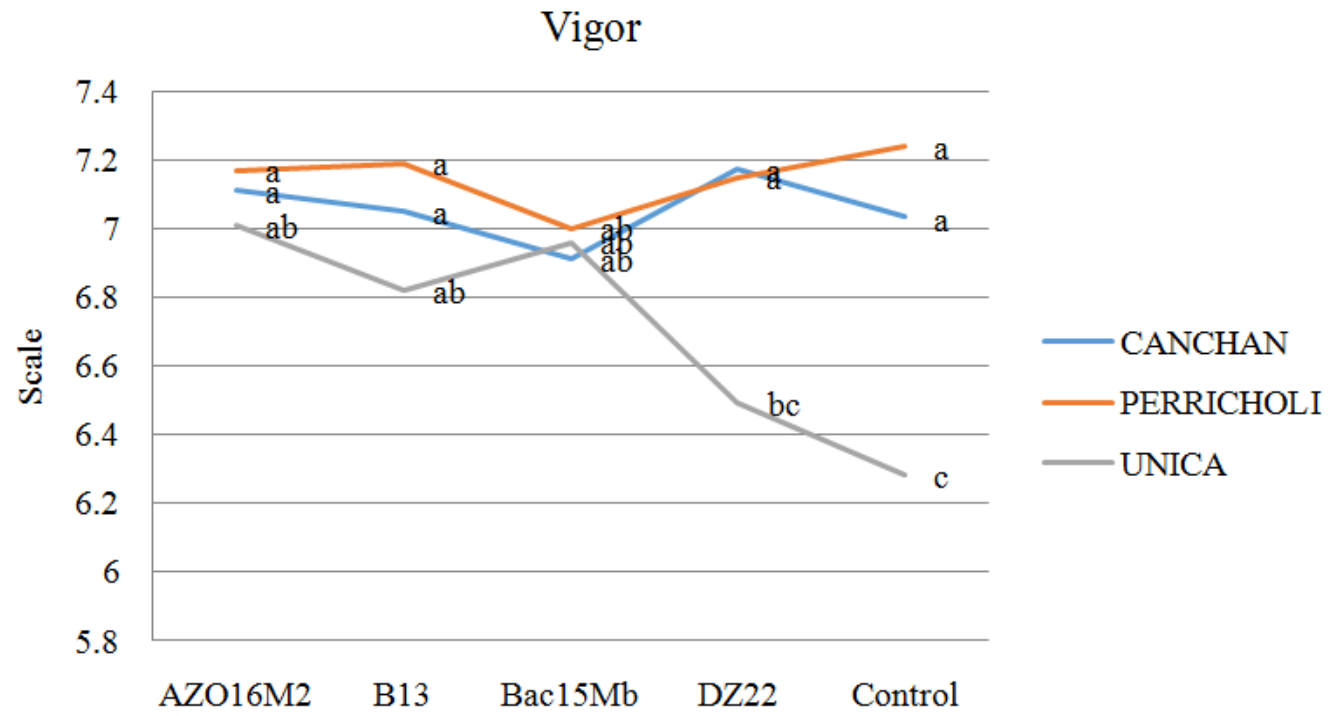

Fig. 1: Vegetative vigor in three potato cultivars under inoculation of bacterial strains 60 days after sowing. Visual scale 1-9. Values with the same letter do not differ significantly $(\mathrm{p}>0,05)$. Azo16M2 = Azotobacter sp. AZO16M2, B13 = Bacillus simplex $\mathrm{B} 13, \mathrm{Bac} 15 \mathrm{MB}=$ Bacillus amyoliquefaciens Bac15MB, DZ22 = Pantoea sp. DZ 22

Flowering percentage

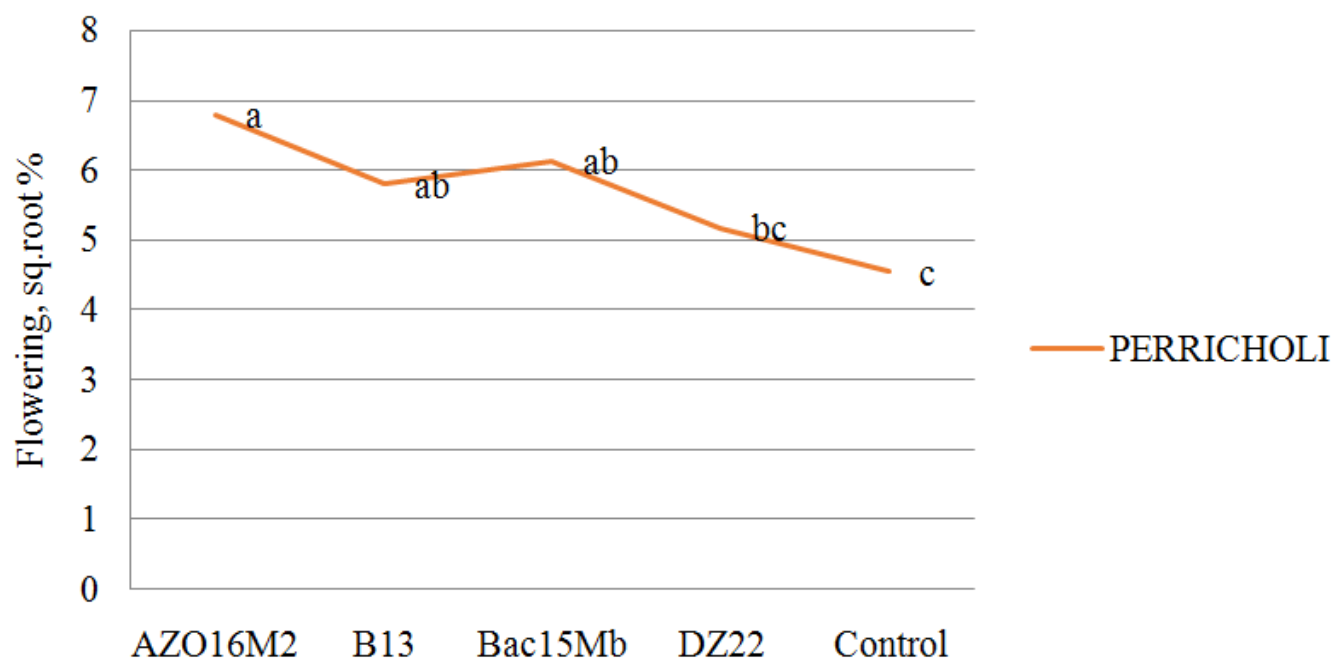

Fig. 2: Percentage of inflorescences in potato cv. Perricholi under bacterial effect, 75 days after planting. Square root transformed data. Values with the same letter do not differ significantly $(\mathrm{p}>0.05)$ 
In Figure 3 is noted that degree of senescence of the foliage was not significant in potato cv. Unica and Perricholi. In cv. Canchán bacterial strains as a whole and in particular strain Bac15MB (Bacillus amyloliquefaciens.) had a slight effect in relation to control, to regulate the degree of senescence of foliage at 105 days of planting.

In Figure 4 we can see that there were significant effects in foliage fresh weight per plant for $\mathrm{cv}$. Perricholi; in this case, strain AZO16M2 (Azotobacter sp.) had significant effects compared to the control and strain DZ22 (Pantoea sp.), obtaining the highest weight value foliage per plant. In potato cv. Canchan and Unica there were no significance.

For tuber yield per hectare, there were no statistical differences between genotypes and bacterial strains within each variety; however, it could be noticed some simple effects, specifically shown by the strain DZ 22 (Pantoea sp.) in cv. Perricholi which reached the highest yield of tubers per hectare $(20.84 \mathrm{t})$ in relation to other bacterial strains but this effect was not consistent in other varieties tested, as shown in Fig. 5.

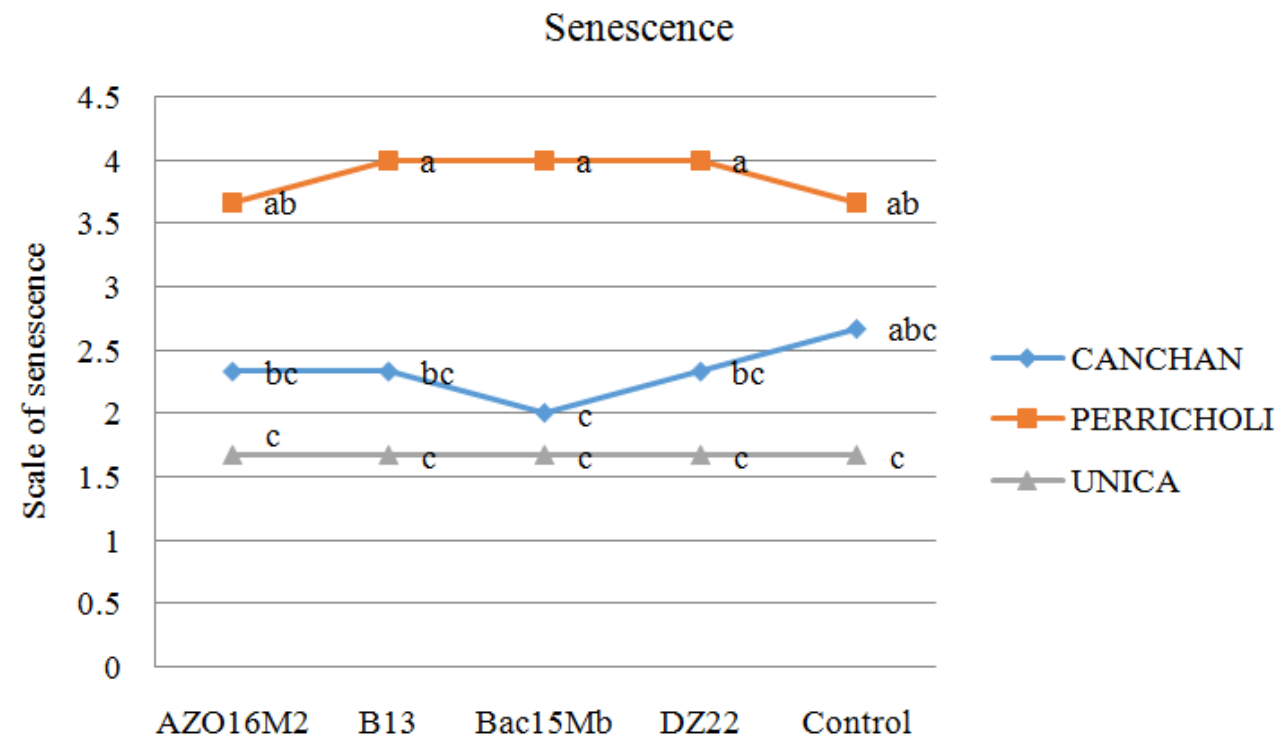

Fig. 3:Degree of senescence of foliage at 105 days in three potato varieties under effect of inoculation of bacterial strains. Phenotypic 1-9 scale (1, completely senescence- 9 , green foliage)

\section{Fresh Weight of Foliage}

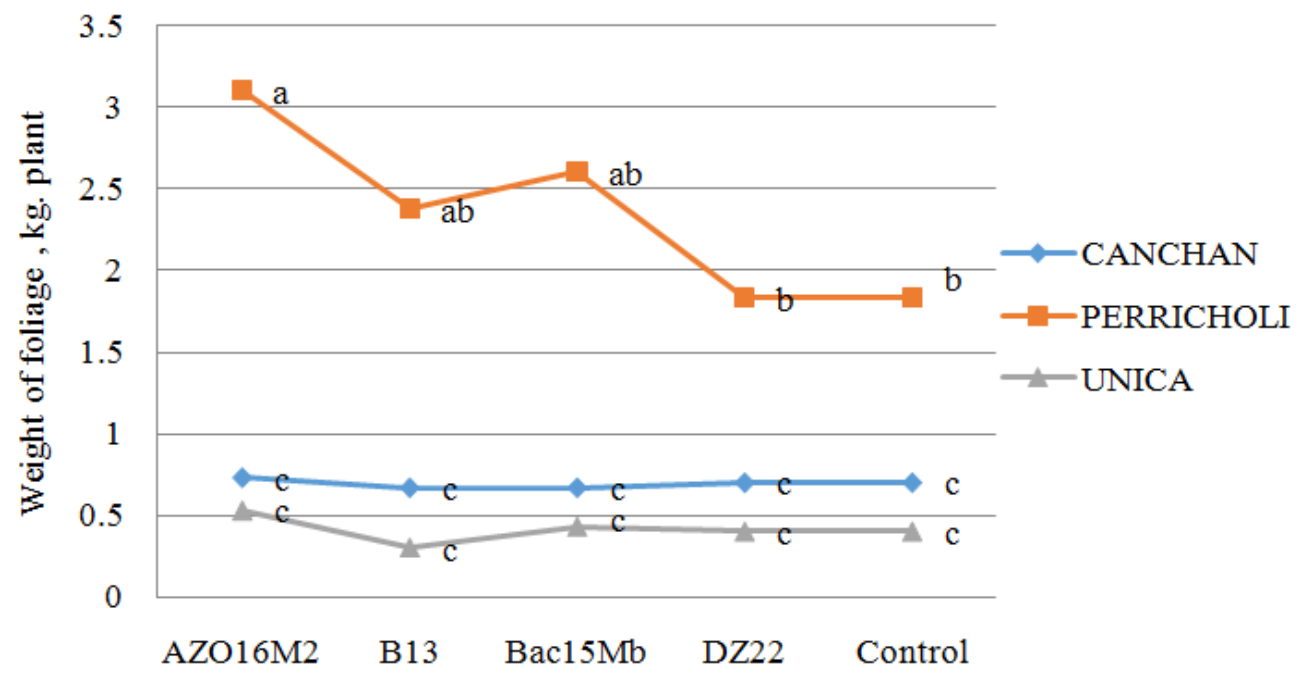

Fig. 4: Foliage fresh weight per plant $(\mathrm{kg})$ at harvest in three potato cultivars under effect of inoculation of bacterial strains 


\section{Tuber yield}

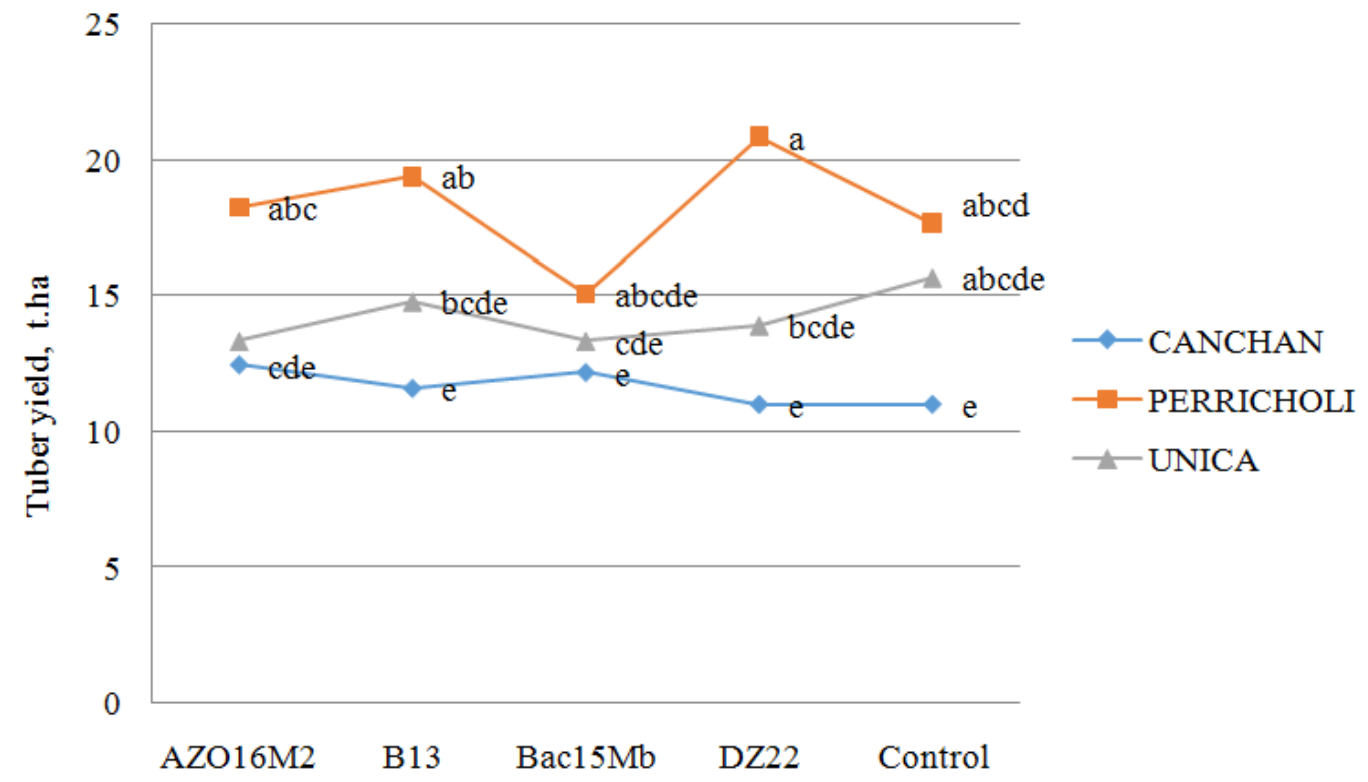

Fig. 5: Tuber yield per hectare (t) in three potato varieties under effect of bacterial strains. Means with the same letter do not differ significantly

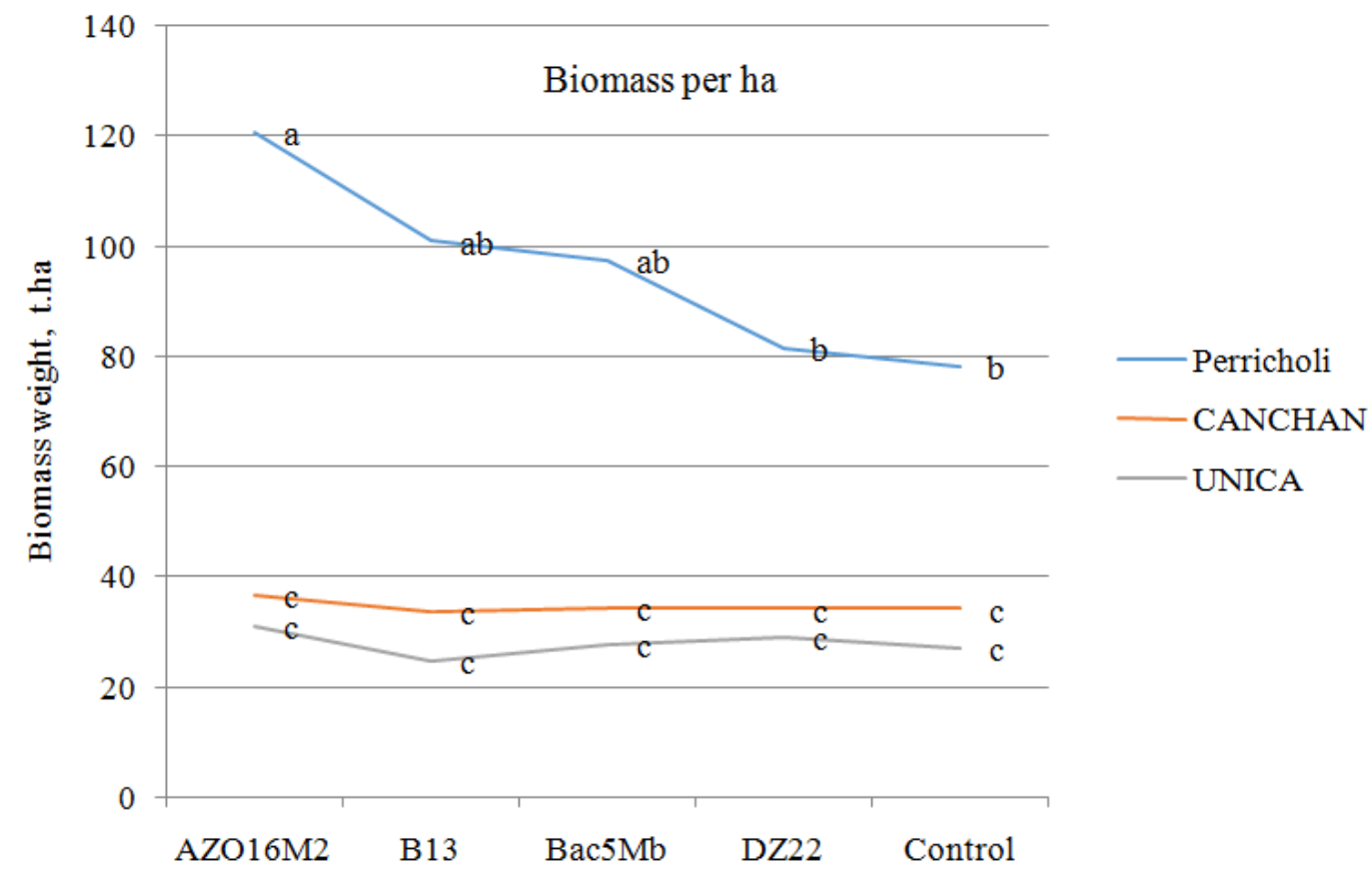

Fig. 6: Fresh weight of biomass per hectare $(t)$ in potato varieties by effect of inoculation of bacterial strains. Values with the same letter do not differ significantly $(\mathrm{p}>0,05)$

In relation to fresh weight of biomass per hectare can be seen in Figure 6 that there were statistical differences just for cv. Perricholi in which the effect of inoculation with bacterial strain AZO16M2 (Azotobacter sp.), was statistically superior to control and treatment of DZ22 strain; in cv. Unica and Canchan there were no differences for inoculation of any rhizobacteria with respect to weight of biomass. 
Table 3: Mean tests for agronomic traits in three potato cultivars as affected by inoculation of bacterial strains

\begin{tabular}{|c|c|c|c|c|c|c|c|c|c|}
\hline $\begin{array}{l}\text { Potato } \\
\text { genotypes }\end{array}$ & Strains & $\begin{array}{l}\text { NSprouts15d/pl } \\
\#\end{array}$ & $\begin{array}{l}\text { PDensity30d } \\
\#\end{array}$ & $\begin{array}{l}\text { Vigor } \\
\text { Scale }\end{array}$ & $\begin{array}{l}\text { HPlant } \\
\mathrm{cm} .\end{array}$ & $\begin{array}{l}\text { \%Virus } \\
\text { transf. } \sqrt{ } \%+1\end{array}$ & $\begin{array}{l}\text { \%LMiner } \\
\%\end{array}$ & $\begin{array}{l}\text { \%Rhizoctonia } \\
\text { transf. } \sqrt{ } \%+1\end{array}$ & $\begin{array}{l}\text { \%Flower } \\
\text { transf. } \sqrt{ } \%+1\end{array}$ \\
\hline \multirow[t]{5}{*}{ Canchan } & AZO16M2 & $2.88 a b c$ & $183.33 \mathrm{ab}$ & $7.11 \mathrm{a}$ & $89.93 \mathrm{a}$ & $1.14 \mathrm{ab}$ & $32.33 \mathrm{a}$ & $1.52 \mathrm{a}$ & $1.00 \mathrm{~d}$ \\
\hline & B13 & $3.07 \mathrm{ab}$ & $187.67 \mathrm{ab}$ & $7.05 \mathrm{a}$ & $89.40 \mathrm{a}$ & $1.14 \mathrm{ab}$ & $33.33 \mathrm{a}$ & $1.61 \mathrm{a}$ & $1.00 \mathrm{~d}$ \\
\hline & Bac15MB & $3.47 \mathrm{a}$ & $199.00 \mathrm{a}$ & $6.91 \mathrm{ab}$ & $88.80 \mathrm{a}$ & $1.00 \mathrm{~b}$ & $31.67 \mathrm{a}$ & $1.67 \mathrm{a}$ & $1.00 \mathrm{~d}$ \\
\hline & DZ22 & $3.15 \mathrm{ab}$ & $176.00 \mathrm{ab}$ & $7.17 \mathrm{a}$ & $88.73 \mathrm{a}$ & $1.4 \mathrm{ab}$ & $30.00 \mathrm{a}$ & $1.71 \mathrm{a}$ & $1.00 \mathrm{~d}$ \\
\hline & Control & $2.84 a b c$ & $207.33 \mathrm{a}$ & $7.03 \mathrm{a}$ & $88.20 \mathrm{a}$ & $1.00 \mathrm{~b}$ & $29.33 \mathrm{a}$ & $1.47 \mathrm{a}$ & $1.00 \mathrm{~d}$ \\
\hline \multirow{5}{*}{ Perricholi } & AZO16M2 & $2.08 \mathrm{bc}$ & $123.00 \mathrm{~b}$ & $1.17 \mathrm{a}$ & $35.27 \mathrm{a}$ & $1.62 \mathrm{ab}$ & $25.00 \mathrm{a}$ & $1.00 \mathrm{a}$ & $6.79 \mathrm{a}$ \\
\hline & B13 & $2.22 \mathrm{bc}$ & $125.33 \mathrm{~b}$ & $7.19 \mathrm{a}$ & $34.60 \mathrm{~b}$ & $1.14 \mathrm{ab}$ & $30.00 \mathrm{a}$ & $1.00 \mathrm{a}$ & $5.79 \mathrm{ab}$ \\
\hline & Bac15MB & $2.13 \mathrm{bc}$ & $121.33 \mathrm{~b}$ & $7.00 \mathrm{ab}$ & $34.40 \mathrm{~b}$ & $1.41 \mathrm{ab}$ & $31.67 \mathrm{a}$ & $1.00 \mathrm{a}$ & $6.12 \mathrm{ab}$ \\
\hline & DZ22 & $1.82 \mathrm{c}$ & $137.67 \mathrm{ab}$ & $7.15 \mathrm{a}$ & $34.20 \mathrm{~b}$ & $1.58 \mathrm{ab}$ & $30.00 \mathrm{a}$ & $1.00 \mathrm{a}$ & $5.16 \mathrm{bc}$ \\
\hline & Control & $2.11 \mathrm{bc}$ & $151.00 \mathrm{ab}$ & $7.24 \mathrm{a}$ & $33.73 \mathrm{~b}$ & $1.71 \mathrm{a}$ & $31.67 \mathrm{a}$ & $1.00 \mathrm{a}$ & $4.54 \mathrm{c}$ \\
\hline \multirow[t]{5}{*}{ Unica } & AZO16M2 & $2.88 \mathrm{abc}$ & $141.00 \mathrm{ab}$ & $7.01 \mathrm{ab}$ & $30.27 \mathrm{c}$ & $1.27 \mathrm{ab}$ & $23.33 \mathrm{a}$ & $1.62 \mathrm{a}$ & $1.00 \mathrm{~d}$ \\
\hline & B13 & $2.82 \mathrm{abc}$ & $136.33 \mathrm{ab}$ & $6.82 \mathrm{ab}$ & $30.27 \mathrm{c}$ & $1.27 \mathrm{ab}$ & $30.00 \mathrm{a}$ & $1.99 \mathrm{a}$ & $1.00 \mathrm{~d}$ \\
\hline & Bac15MB & $2.93 \mathrm{ab}$ & $143.67 \mathrm{ab}$ & $6.96 \mathrm{ab}$ & $29.87 \mathrm{c}$ & $1.00 \mathrm{~b}$ & $25.00 \mathrm{a}$ & $1.62 \mathrm{a}$ & $1.00 \mathrm{~d}$ \\
\hline & DZ22 & $2.67 \mathrm{abc}$ & $154.67 \mathrm{ab}$ & $6.49 \mathrm{bc}$ & $29.60 \mathrm{c}$ & $1.14 \mathrm{ab}$ & $26.67 \mathrm{a}$ & $1.48 \mathrm{a}$ & $1.00 \mathrm{~d}$ \\
\hline & Control & $3.08 \mathrm{ab}$ & $158.33 \mathrm{ab}$ & $6.28 \mathrm{c}$ & $29.07 \mathrm{c}$ & $1.14 \mathrm{ab}$ & $26.67 \mathrm{a}$ & $1.58 \mathrm{a}$ & $1.00 \mathrm{~d}$ \\
\hline Standard error & & 0.21 & 13.44 & 0.1 & 0.53 & 0.13 & 2.02 & 0.2 & 0.23 \\
\hline
\end{tabular}

*Means with different letter in columns, are statistically significant for Tukey test $(\mathrm{p}<0.05)$

Table 4: Mean tests for production traits in three potato cultivars as affected by inoculation of bacterial strains

\begin{tabular}{|c|c|c|c|c|c|c|c|c|c|}
\hline $\begin{array}{l}\begin{array}{l}\text { Potato } \\
\text { genotypes }\end{array} \\
\end{array}$ & Strains & $\begin{array}{l}\text { Senescence } \\
\text { Scale }\end{array}$ & $\begin{array}{l}\text { WFoliage } \\
k \cdot p^{-1}\end{array}$ & $\begin{array}{l}\text { NTubers } \\
\#\end{array}$ & $\begin{array}{l}\text { WTubers } \\
k .\end{array}$ & $\begin{array}{l}\text { HAspect } \\
\text { Scale }\end{array}$ & $\begin{array}{l}\text { WTubers/pl } \\
k \cdot p^{-1}\end{array}$ & $\begin{array}{l}\text { Yield } \\
t . h a^{-1}\end{array}$ & $\begin{array}{l}\text { Biomass } \\
t . h a^{-1}\end{array}$ \\
\hline \multirow[t]{5}{*}{ Canchan } & AZO16M2 & $2.33 \mathrm{bc}$ & $0.73 \mathrm{c}$ & $320.7 \mathrm{a}$ & 14.33 cde & $3.67 \mathrm{a}$ & $0.38 \mathrm{cde}$ & 12.44 cde & $36.64 \mathrm{c}$ \\
\hline & B13 & $2.33 \mathrm{bc}$ & $0.67 \mathrm{c}$ & $305.0 \mathrm{ab}$ & $13.33 \mathrm{e}$ & $4.00 \mathrm{a}$ & $0.35 \mathrm{e}$ & $11.58 \mathrm{e}$ & $33.58 \mathrm{c}$ \\
\hline & Bac15MB & $2.00 \mathrm{c}$ & $0.67 \mathrm{c}$ & $311.0 \mathrm{ab}$ & $14.00 \mathrm{de}$ & $4.00 \mathrm{a}$ & $0.37 \mathrm{de}$ & $12.16 \mathrm{de}$ & $34.16 \mathrm{c}$ \\
\hline & DZ22 & $2.33 \mathrm{bc}$ & $0.70 \mathrm{c}$ & $290.67 \mathrm{ab}$ & $12.67 \mathrm{e}$ & $4.00 \mathrm{a}$ & $0.33 \mathrm{e}$ & $11.00 \mathrm{e}$ & $34.10 \mathrm{c}$ \\
\hline & Control & $2.67 \mathrm{abc}$ & $0.70 \mathrm{c}$ & $260.0 \mathrm{ab}$ & $12.67 \mathrm{e}$ & $4.67 \mathrm{a}$ & $0.33 \mathrm{e}$ & $11.00 \mathrm{e}$ & $34.10 \mathrm{c}$ \\
\hline \multirow[t]{5}{*}{ Perricholi } & AZO16M2 & $3.67 \mathrm{ab}$ & $3.10 \mathrm{a}$ & $259.0 \mathrm{ab}$ & $21.00 \mathrm{abc}$ & $3.67 \mathrm{a}$ & $0.55 \mathrm{ab}$ & $18.24 \mathrm{abc}$ & $120.54 \mathrm{a}$ \\
\hline & B13 & $4.00 \mathrm{a}$ & $2.37 \mathrm{ab}$ & $263.7 \mathrm{ab}$ & $22.33 \mathrm{ab}$ & $3.00 \mathrm{a}$ & $0.59 \mathrm{ab}$ & $19.39 \mathrm{ab}$ & $100.85 \mathrm{ab}$ \\
\hline & Bac15MB & $4.00 \mathrm{a}$ & $2.60 \mathrm{ab}$ & $273.0 \mathrm{ab}$ & 17.33 abcde & $3.67 \mathrm{a}$ & 0.46 abcde & 15.05 abcde & $97.49 \mathrm{ab}$ \\
\hline & $\mathrm{DZ} 22$ & $4.00 \mathrm{a}$ & $1.83 \mathrm{~b}$ & $236.7 \mathrm{ab}$ & $24.00 \mathrm{a}$ & $4.00 \mathrm{a}$ & $0.63 \mathrm{a}$ & $20.84 \mathrm{a}$ & $81.34 \mathrm{~b}$ \\
\hline & Control & $3.67 \mathrm{ab}$ & $1.83 \mathrm{~b}$ & $253.7 \mathrm{ab}$ & $20.33 \mathrm{abcd}$ & $3.67 \mathrm{a}$ & $0.54 \mathrm{abcd}$ & $17.66 \mathrm{abcd}$ & $78.16 \mathrm{~b}$ \\
\hline \multirow{5}{*}{ Unica } & AZO16M2 & $1.67 \mathrm{c}$ & $0.53 \mathrm{c}$ & $202.7 \mathrm{~b}$ & $15.33 \mathrm{cde}$ & $4.00 \mathrm{a}$ & 0.4 cde & 13.32 cde & $30.92 \mathrm{c}$ \\
\hline & $\mathrm{B} 13$ & $1.67 \mathrm{c}$ & $0.30 \mathrm{c}$ & $221.7 \mathrm{ab}$ & 17.00 bcde & $5.33 \mathrm{a}$ & 0.45 bcde & 14.76 bcde & $24.66 \mathrm{c}$ \\
\hline & Bac15MB & $1.67 \mathrm{c}$ & $0.43 \mathrm{c}$ & $205.0 \mathrm{~b}$ & $15.33 \mathrm{cde}$ & $4.33 \mathrm{a}$ & 0.40 cde & $13.32 \mathrm{cde}$ & $27.62 \mathrm{c}$ \\
\hline & DZ22 & $1.67 \mathrm{c}$ & $0.40 \mathrm{c}$ & $228.0 \mathrm{ab}$ & 16.00 bcde & $4.33 \mathrm{a}$ & $0.42 \mathrm{bcde}$ & 13.89 bcde & $28.83 \mathrm{c}$ \\
\hline & Control & $1.67 \mathrm{c}$ & $0.40 \mathrm{c}$ & $239.7 \mathrm{ab}$ & 18.00 abcde & $4.00 \mathrm{a}$ & 0.47 abcde & 15.63 abcde & $27.09 \mathrm{c}$ \\
\hline Standard error & & 0.3 & 0.18 & 20.6 & 5.16 & 0.49 & 0.03 & 1.14 & 6.01 \\
\hline
\end{tabular}

*Means with different letter in columns, are statistically significant for Tukey test $(\mathrm{p}<0.05)$

- PDensity $=$ number of stems per area observed at 30 days after sowing

- $N$ Sprouts $15 \mathrm{~d} / \mathrm{pl}$. = number of sprouts per plant emerged at 15 days after planting

- Vegetative vigor $=$ measured on a phenotypic scale of 1 to 9

- HPlant $=$ plant height at 60 days after planting

- $\%$ Virus = percentage of plants with visual symptoms of viral infection(data transformed square root)

- $\%$ LMiner $=$ percentage of damaged plants with leafminer fly 60 days after planting

- $\%$ Rhizoctonia $=$ percentage of affected plants with Rhizoctonia solani at 60 days after planting (square root transformed data).

- $\%$ Flower $=$ Percentage of flowering plants at 75 days of planting (data processed square root)

- Senescence $=$ Degree of senescence foliage at 100 days, measured in phenotypic scale from 1 to 9

- WFoliage = weight of fresh foliage per plot at harvest

- NTubers $=$ number of tubers per plot at harvest

- WTubers $=$ weight of tubers per plot at harvest

- HAspect = overall appearance of the harvest measured in phenotypic scale from 1 to 9

- WTuber $/ p l=$ average fresh weight of tubers per plant

- Yield $h a^{-1}=$ projected yield of tubers for 30000 plants.ha $^{-1}$

- Biomass $=$ total weight of the biomass (tubers + foliage) projected per hectare

Interactions between potato genotypes and bacterial strains can be showed in Tables 3 and 4. No significant interactions were found for most traits evaluated, except for plant vigor and flowering percentage. There were also interactions for some production traits as plant senescence and biomass for cv. Canchan and Perricholi, respectively. 


\section{Discussion}

Inoculation of seed tubers of potato cultivars Canchan, Perricholi and Unica, significantly influenced the following characters: vegetative vigor, percentage of inflorescences, weight of foliage per plot and weight of the total biomass per hectare, in which significant interactions between varieties of potato and bacterial strains also were presented. This is consistent with the findings by Calvo and Zúñiga (2010) who observed an effect of potato variety on populations of microorganisms in the rhizosphere, which may explain the interaction effects between potato genotypes and bacterial strains in some characters, such as we found in this investigation.

No significant changes showed in the sources of inoculation with the bacterial strains or its interactions with potato genotypes with regard to yield of tubers per hectare or some of its components, but significantly, there were some specific effects of inoculation of bacterial strains on potato genotypes. In this regard, Oswald et al. (2010) claim that three rhizobacteria of the taxa Bacillus, Actinomycete and Azotobacter increased tuber yield significantly, comparable with the yields of different varieties of potato with inorganic fertilization, under greenhouse and field conditions in Peru, results that agree partially with findings in this investigation, although growing conditions and the varieties used in both cases, were different.

Relative to the total weight of the biomass was observed only statistical differences for cv. Perricholi, in which the effect of inoculation with the bacterial strain AZO16M2 (Azotobacter sp.), was statistically superior to control; Rico (2009) reported similar results with Azotobacter strains showed plant growth promotion, potato tuber production and solubilization of phosphates.

\section{Conclusion}

Some concluding remarks can be suggested from the present research for agronomical response of potato cultivars inoculated by bacterial strains:

- Vigor: there was a significant interactive effect for vegetative vigor between potato genotypes and bacterial strains and a differential response to inoculation with bacterial strain AZO16M2 (Azotobacter sp.) in cv. Unica

- Flowering: tuber seed inoculated with bacterial strain AZO16M2 (Azotobacter sp.) in potato cv. Perricholi showed a greater effect in flowering percentage

- Senescence: In cv. Canchan bacterial strains as a whole, and in particular strain Bac15MB (Bacillus amyloliquefaciens) had a slight effect in regulating senescence compared to control
- Foliage fresh weight: significant effects for cv. Perricholi, in this case for strain AZO16M2 (Azotobacter sp.)

- Total Biomass per hectare: For cv. Perricholi the effect of inoculation with bacterial strain AZO16M2 (Azotobacter sp.) was significant

It can be concluded that the inoculation with bacterial strains studied in potato genotypes Canchán, Perricholi and Unica, can be an appropriate technology to promote potato growth in important agronomic characters, although its specific effect is dependent on each genotype, so that may be recommended some bacterial strains for use as inoculation treatment having a stimulatory effect for development in these commercial varieties.

\section{Acknowledgement}

This research was financed with funds from the Regional Canon and Camisea Gas (FOCAM) promoted by the Universidad Nacional Jose Faustino Sánchez Carrion-Huacho, which allowed the execution of the project during 2015 . We also recognized the contribution of the following Agronomist to participate directly in the development of the project in Huacho and Cañete: Luis Luyo Sanchez, Rosalila Carhuajulca, Monica Gonzales, Juan Carlos Bravo and Gloria Rivera, as well as the administrative staff of University Research Office: Amalia Gonzales, Yuri Gamonal, Adolfo Figueroa, Rossana Garrido and María Julia Fernández.

\section{Author's Contributions}

Sergio Eduardo Contreras Liza: Literature review, analyzed and interpreted results and conclusions, and made the correspondence of the submitted paper.

Juan Carlos Custodio Laura: Conducted and designed the experiments in field conditions.

Doris Elizabeth Zúñiga Dávila: Supervised experimental work, laboratory facilities and revised the manuscript.

Sady García Bendezú: Supervised experimental work and revised the final manuscript.

\section{Ethics}

This article is original. Authors declare that are not ethical issues that may arise after the publication of this manuscript and does not have similar content with papers that has been published.

\section{References}

Balzarini, M.G., L. Gonzalez, M. Tablada, F. Casanoves and J.A. DI Rienzo et al., 2014. InfosTat. Manual del Usuario. Editorial Brujas, Córdoba, Argentina. 
Calvo, P. and D. Zúñiga, 2010. Caracterización fisiológica de cepas de Bacillus spp. aisladas de la rizósfera de papa (Solanum tuberosum). Ecol. Aplicada, 9: 31-39.

Calvo, P., L. Reymundo and D. Zuñiga, 2008. Estudio de las poblaciones microbianas de la rizósfera del cultivo de papa (Solanum tuberosum) en zonas altoandinas. Ecol. Aplicada, 7: 141-148.

CIP, 2013. Genetics and Crop Improvement; Integrated IT and Computational Research. International Potato Center, Catalogue of potato varieties and advanced clones [CD-ROM]. Lima.

Egamberdieva, D., 2012. The Management of Soil Quality and Plant Productivity in Stressed Environment with Rhizobacteria. In: Bacteria in Agrobiology: Stress Management, Maheshwari, D.K. (Edn.), Springer-Verlag Berlin Heidelberg.

FAO, 2008. Producción de tubérculos semillas libres de enfermedades. El año internacional de la papa 2008. Secretaria del año internacional de la Papa. FAO. ROMA.

Gutiérrez-Rosales, R.O., J.A. Espinoza-Trelles and M. Bonierbale, 2007. UNICA: variedad Peruana para Mercado fresco y papa frita con tolerancia y resistencia para condiciones climáticas adversas. Revista Latinoamericana de la Papa. 14: 41-50.

Maheshwari D K. 2011. Bacteria in Agrobiology: Crop Ecosystems. DOI 10.1007/978-3-642-18357-7_2, Springer-Verlag Berlin, Heidelberg
Maldonado, L., V. Suárez and G. Thiele, 2008. Estudio de la adopción de variedades de papa en zonas pobres del Perú. Centro Internacional de la Papa (CIP). Lima-Perú. Documento de Trabajo, pp: 37.

Oswald, A, P. Calvo, D. Zuñiga and J. Arcos, 2010. Evaluating soil rhizobacteria for their ability to enhance plant growth and tuber yield in potato. Ann. Appl. Biol., 157: 259-271. DOI: $10.1111 / \mathrm{j} .1744-7348.2010 .00421 . \mathrm{x}$

Pineda, R., 1999. Empleo del rastrojo de algodón en la preparación de fosfo-compost y su efecto en el cultivo de maíz en Piura. En: Manejo Ecológico de Suelos. Conceptos, Experiencias y Técnicas. Editado por: Luis Gomero O. y Héctor Velásquez A. Red de Acción en Alternativas al uso de Agroquímicos. Lima.

Pineda, S.J., J.J. Zheng, A. Van Loon and M. Dicke, 2012. Plant biology. Special Issue: Plant-Pathogen Interactions, 14: 83-90.

Rico, M.A., 2009. Capacidad promotora del crecimiento vegetal por bacterias del género Azotobacter y actinomicetos aislados de cultivos de Solanum tuberosum Linnaeus, 1753 (papa) cultivados en zonas alto andinas del Perú. Thesis for Biologist. Universidad Nacional Mayor de San Marcos. Lima.

Steel, R., J. Torrie and D.A. Dickey, 1997. Principles and procedures of statistics: A biometrical approach. McGraw-Hill, pp: 666. 